Supporting Information for

\title{
Olefin Metathesis of the Aligned Assemblies of Conjugated Polymers Constructed through Supramolecular Bundling
}

\author{
Rie Wakabayashi, Yohei Kubo, Kenji Kaneko†, \\ Masayuki Takeuchi,* and Seiji Shinkai* \\ Contribution from Department of Chemistry and Biochemistry, Graduate School of \\ Engineering, Kyushu University, Fukuoka 819-0395, Japan, and ${ }^{\dagger}$ HVEM Laboratory, \\ Kyushu University, Fukuoka 812-8581, Japan \\ E-mail: taketcm@mbox.nc.kyushu-u.ac.jp (M.T)
}

\section{Experimantal}

\section{General.}

All starting materials and solvents were purchased from Tokyo Kasei Chemicals or Wako Chemicals and used as received. The ${ }^{1} \mathrm{H}$ NMR spectra were recorded on a Brucker DRX 600 (600 MHz) spectrometer. Chemical shifts are reported in ppm downfield from tetramethylsilane as the internal standard. Mass spectral data were obtained using a Perseptive Voyager RP MALDI TOF mass spectrometer and/or a JEOL JMS HX110A high-resolution magnetic sector FAB mass spectrometer. UV-Vis and fluorescence spectra were recorded using Shimadzu UV-2500 PC and Perkin-Elmer LS55 spectrophotometers.

Transmission Electron Microscopy (TEM) and High-Resolution TEM (HRTEM). TEM and HRTEM images were acquired using a JEOL TEM-2010 (accelerating voltage: $120 \mathrm{kV}$ ) and a TECNAI-20 FEI (accelerating voltage: $200 \mathrm{kV}$ ), respectively. A sample solution was placed on a copper TEM grid upon a holey carbon support film. The TEM grid was dried under reduced pressure for $6 \mathrm{~h}$ prior to TEM observation. 


\section{RCM reaction.}

Compound 1o $(0.57 \mathrm{mM})$ was complexed with $\mathbf{C P 1}\left(\left[\mathbf{C P 1} \mathbf{1}_{\text {unit }}\right]=8.6 \mathrm{mM}\right)$ in chloroform- $d_{l}$ at $25{ }^{\circ} \mathrm{C}$ for $24 \mathrm{hrs}$; we confirmed by UV-Vis spectroscopy that 10 ${ }^{\bullet}$ (diamine unit in CP1) $)_{2}$ complex is formed quantitatively and no spectral change was observed during the aging period. Then Hoveyda-Grubbs catalyst $\mathbf{3}$ was added was added to the solution ( $6 \mathrm{~mol} \%$ of the catalyst was added every $1 \mathrm{hr}$, in total $60 \mathrm{~mol} \%$ ) and the resulting mixture was reacted at $60{ }^{\circ} \mathrm{C}$ with microwave irradiation $(110 \mathrm{~W}, 20$ bar) for 10 hrs. The time course of the reaction was monitored by ${ }^{1} \mathrm{H}$ NMR.

\section{Sample Preparation for TEM Measurement.}

A chloroform solution of the separated assemblies by SEC after RCM reaction was cast on a copper TEM grid upon a holey carbon support film. 


\section{Synthesis.}

Compound 1o was synthesized according to Scheme S1. Synthetic procedures for compounds $\mathbf{2}$ and $\mathbf{3}$ were reported previously. ${ }^{1)}$

\section{Scheme S1.}
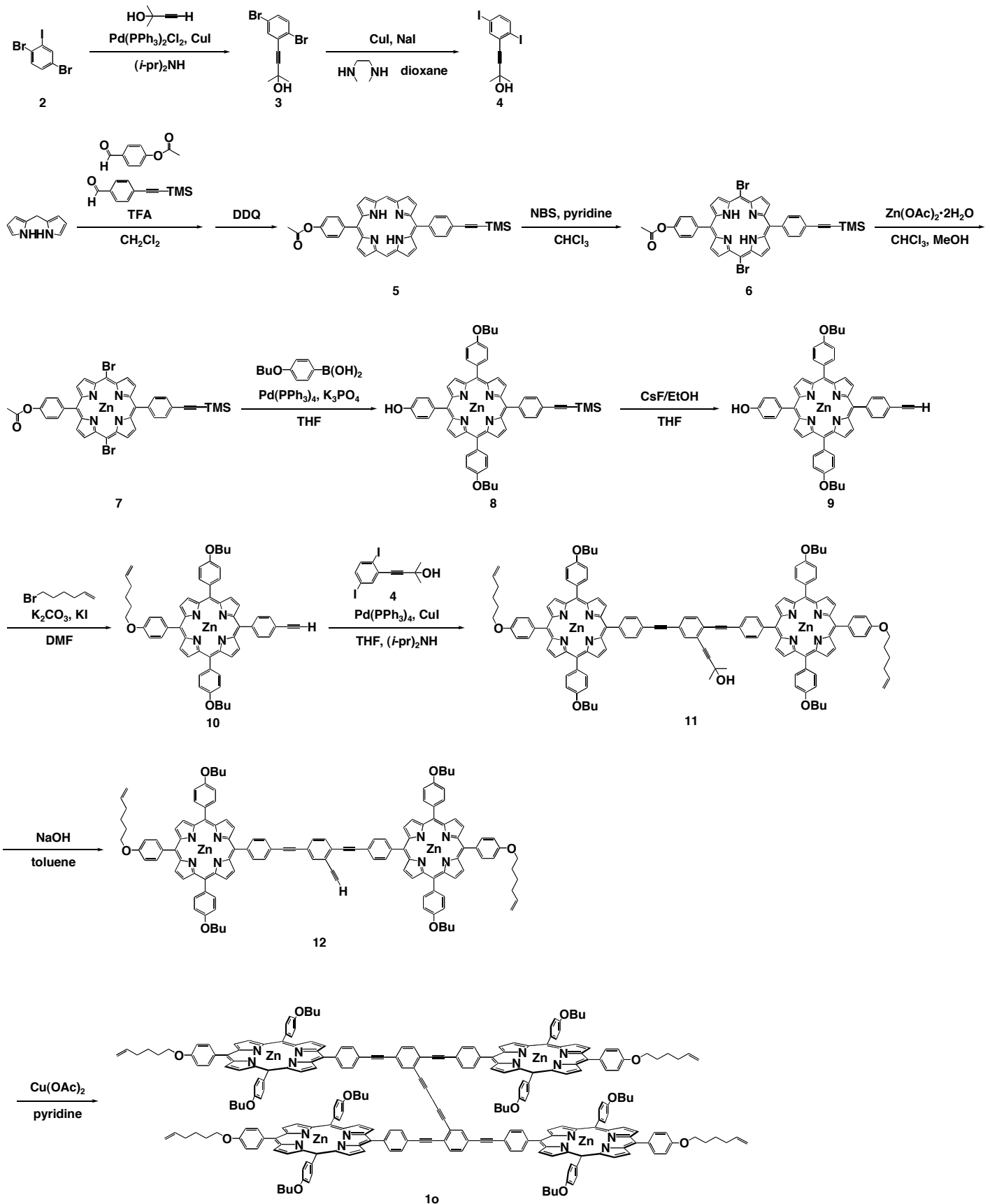
Compound 4. In a $25 \mathrm{ml}$ of two neck flask, $N, N$ '-dimethylethylenediamine (86 $\mu \mathrm{L}$, $0.80 \mathrm{mmol}, 0.4 \mathrm{eq} . / 3)$ was added to a dioxane solution $(2.0 \mathrm{ml})$ of $\mathbf{3}(0.64 \mathrm{~g}, 2.0 \mathrm{mmol})$, $\mathrm{CuI}(76 \mathrm{mg}, 0.40 \mathrm{mmol}, 0.2 \mathrm{eq.} / 3)$ and $\mathrm{NaI}\left(1.2 \mathrm{~g}, 8.0 \mathrm{mmol}, 4\right.$ eq./3) under $\mathrm{N}_{2}$ atmosphere. The solution was stirred at $110{ }^{\circ} \mathrm{C}$ for 44.5 hours. Then $\mathrm{CuI}(37 \mathrm{mg}, 0.20$ mmol, 0.1 eq./3), NaI (1.2 g, 8.0 mmol, 4 eq./3), $N, N^{\prime}$-dimethylethylenediamine ( $86 \mu \mathrm{L}$, $0.80 \mathrm{mmol}, 0.4$ eq. $/ 3)$, dioxane $(5.0 \mathrm{~mL})$ was added to the solution and the solution was stirred at $110{ }^{\circ} \mathrm{C}$ for 66 hours. Dichloromethane $(20 \mathrm{~mL})$ was added to the reaction mixture and the solution was washed by $3 \%$ aqueous $\mathrm{NH}_{3}(30 \mathrm{~mL} \mathrm{X} 2)$ and $\mathrm{H}_{2} \mathrm{O}(30$ $\mathrm{mL}$ ). The organic solvent was dried over anhydrous $\mathrm{MgSO}_{4}$. The insoluble materials were filtered off and the filtrate was evaporated. The residue was purified by flash chromatography (silica gel, dichloromethane). Compound $\mathbf{4}$ was obtained as the mixture with mono-iodo-substituted byproduct (the ratio of 4 is about 0.98 ). The mixture was used to following synthesis without further purification. ${ }^{1} \mathrm{H}$ NMR (600 $\mathrm{MHz}, \mathrm{CD}_{2} \mathrm{Cl}_{2}$, TMS standard, r.t.); $\delta 1.61(6 \mathrm{H}, \mathrm{s}), 7.32(1 \mathrm{H}, \mathrm{d}-\mathrm{d}(J=8.3-1.9 \mathrm{~Hz})), 7.55$ $(1 \mathrm{H}, \mathrm{d}(J=8.3 \mathrm{~Hz})), 7.76(1 \mathrm{H}, \mathrm{d}(J=1.9))$.

Compound 5. In a $2 \mathrm{~L}$ of two neck flask, TFA $(0.35 \mathrm{~mL})$ was added to a dichloromethane $(1.3 \mathrm{~L})$ solution of dipyrromethane $(1.0 \mathrm{~g}, 6.8 \mathrm{mmol})$, 4-trimethylsilylethynylbenzaldehyde $\left(\begin{array}{llllll}0.69 & \mathrm{~g}, & 3.4 & \mathrm{mmol}, & 0.5 & \text { eq. })\end{array}\right.$ and 4-acetoxybenzaldehyde $(0.47 \mathrm{~mL}, 3.4 \mathrm{mmol}, 0.5$ eq. $)$ under $\mathrm{N}_{2}$ atmosphere. The solution was stirred at room temperature for 4.5 hours without light. Then DDQ $(2.0 \mathrm{~g}$, $8.8 \mathrm{mmol}$ ) was added to the reaction mixture. The crude product was purified by flash chromatography (silica gel, chloroform) and column chromatography (silica gel, chloroform; $\left.\mathrm{R}_{\mathrm{f}}=0.39\right)$ to produce a purple solid (406 mg, $\left.19 \%\right)$. ${ }^{1} \mathrm{H}$ NMR (600 MHz, $\mathrm{CDCl}_{3}$, TMS standard, r.t.); $\delta-3.14(2 \mathrm{H}, \mathrm{s}), 0.40(9 \mathrm{H}, \mathrm{s}), 2.52(3 \mathrm{H}, \mathrm{s}), 7.56(2 \mathrm{H}, \mathrm{d}(J=8.0$ $\mathrm{Hz})), 7.93(2 \mathrm{H}, \mathrm{d}(J=7.6 \mathrm{~Hz})), 8.22(2 \mathrm{H}, \mathrm{d}(J=7.7 \mathrm{~Hz})), 8.28(2 \mathrm{H}, \mathrm{d}(J=8.1 \mathrm{~Hz})), 9.05(2 \mathrm{H}$, $\mathrm{d}(J=4.4 \mathrm{~Hz})), 9.11(2 \mathrm{H}, \mathrm{d}(J=4.4 \mathrm{~Hz})), 9.41(4 \mathrm{H}, \mathrm{m}), 10.33(2 \mathrm{H}, \mathrm{s})$. MALDI TOF MS (dithranol) : found 616.2867 (calcd for $[\mathrm{M}+\mathrm{H}]^{+}=616.23$ ). Anal. Calcd. For $\mathrm{C}_{39} \mathrm{H}_{32} \mathrm{~N}_{4} \mathrm{O}_{2} \mathrm{Si} \mathrm{C}, 75.95 ; \mathrm{H}, 5.23 ; \mathrm{N}, 9.08$. Found: C, 74.71; H, 5.25; N, 8.93.

Compound 6. In a $500 \mathrm{~mL}$ of Erlenmeyer flask, $N$-bromoscineimide (NBS) $(0.21 \mathrm{~g}$, $1.2 \mathrm{mmol}, 2 \mathrm{eq} . / \mathbf{5})$ was added to a chloroform $(200 \mathrm{~mL})$ and pyridine $(2.0 \mathrm{~mL})$ solution of $5(0.37 \mathrm{~g}, 0.60 \mathrm{mmol})$. The reaction mixture was stirred at $0{ }^{\circ} \mathrm{C}$ for 40 minutes. 
Then acetone $(4.0 \mathrm{ml})$ was added to quench residual NBS. The solvent was evaporated and the residue was washed by methanol to produce a purple solid $(412 \mathrm{mg}, 89 \%) .{ }^{1} \mathrm{H}$ NMR (600 MHz, $\mathrm{CDCl}_{3}$, TMS standard, r.t.); $\delta-2.77$ (2H, s), 0.40 (9H, s), $2.51(3 \mathrm{H}, \mathrm{s})$, $7.52(2 \mathrm{H}, \mathrm{d}(J=8.1 \mathrm{~Hz})), 7.88(2 \mathrm{H}, \mathrm{d}(J=7.7 \mathrm{~Hz})), 8.09(2 \mathrm{H}, \mathrm{d}(J=7.7 \mathrm{~Hz})), 8.15(2 \mathrm{H}$, $\mathrm{d}(J=8.0 \mathrm{~Hz})), 8.79(2 \mathrm{H}, \mathrm{s}), 8.85(2 \mathrm{H}, \mathrm{s}), 9.61(4 \mathrm{H}, \mathrm{s})$. MALDI TOF MS (dithranol) ; Obs. $772.0465\left(\mathrm{Cal}\right.$. for $\left.[\mathrm{M}+\mathrm{H}]^{+}=772.05\right)$. HR FABMS; found 772.0509 (calcd for $\left.[\mathrm{M}+\mathrm{H}]^{+}=772.0505\right)$.

Compound 7. In a $300 \mathrm{~mL}$ of round-bottomed flask, a methanol solution (40 mL) of zinc(II)acetate (1.33 g, $7.2 \mathrm{mmol}, 10$ eq./6) was added to a chloroform solution (300 $\mathrm{mL})$ of $6(0.56 \mathrm{~g}, 0.72 \mathrm{mmol})$. The reaction mixture was stirred at room temperature for 4 hours. The solvent was evaporated and chloroform was added to the residue. The insoluble materials were filtered off and the filtrate was washed by $\mathrm{H}_{2} \mathrm{O}$ (2 times), dried over anhydrous $\mathrm{Na}_{2} \mathrm{SO}_{4}$. The crude product was purified by reprecipitation (THF/methanol) to produce a purple solid (486 mg, >100\%). ${ }^{1} \mathrm{H}$ NMR (600 MHz, $\mathrm{CDCl}_{3}$, TMS standard, r.t.); $\delta 0.37$ (9H, s), $2.43(3 \mathrm{H}, \mathrm{s}), 7.53(2 \mathrm{H}, \mathrm{d}(J=8.2 \mathrm{~Hz})), 7.86(2 \mathrm{H}, \mathrm{d}(J=7.7 \mathrm{~Hz})), 8.14(2 \mathrm{H}, \mathrm{d}(J=8.1 \mathrm{~Hz}))$, $8.16(2 \mathrm{H}, \mathrm{d}(J=8.3 \mathrm{~Hz})), 8.84(2 \mathrm{H}, \mathrm{s}), 8.88(2 \mathrm{H}, \mathrm{s}), 9.67(4 \mathrm{H}, \mathrm{m})$. MALDI TOF MS (dithranol) ; Obs. 833.9636 (Cal. for $\left.[\mathrm{M}+\mathrm{H}]^{+}=833.96\right)$. HR FABMS; found 833.9631 (calcd for $[\mathrm{M}+\mathrm{H}]^{+}=833.9640$ ). Anal. Calcd. For $\mathrm{C}_{39} \mathrm{H}_{28} \mathrm{Br}_{2} \mathrm{~N}_{4} \mathrm{O}_{2} \mathrm{SiZn} \bullet 1.5 T H F \mathrm{C}, 57.13$; H, 4.26; N, 5.92. Found: C, 57.13; H, 4.26; N, 5.92.

Compound 8. In a $500 \mathrm{~mL}$ of three neck flask, tetrakis(triphenylphosphine)-palladium(0) $(55 \mathrm{mg}, 48 \mu \mathrm{mol}, 0.1 \mathrm{eq} . / 7)$ was added to an anhydrous THF solution (70 mL) of 7 (0.40 g, $0.48 \mathrm{mmol}), \mathrm{K}_{3} \mathrm{PO}_{4}(2.0 \mathrm{~g}, 9.5 \mathrm{mmol}, 20$ eq./7), and 4-butoxyphenylboronic acid (0.93 g, $4.8 \mathrm{mmol}, 10$ eq./7) under $\mathrm{N}_{2}$ atmosphere. The reaction was kept under reflux for 24 hours and protected from light. After an addition of THF to the resulting mixture, the insoluble materials were filtered off. The filtrate was evaporated and the residue was purified by flash chromatography ( silica gel, THF) and column chromatography (silica gel, dichloromethane: $n$-hexane $=$ $4: 1)$ to produce a purple solid $(0.18 \mathrm{~g}, 40 \%)$. ${ }^{1} \mathrm{H}$ NMR $\left(600 \mathrm{MHz}, \mathrm{CDCl}_{3}, \mathrm{TMS}\right.$ standard, r.t.); $\delta 0.38(9 \mathrm{H}, \mathrm{s}), 1.11(6 \mathrm{H}, \mathrm{m}), 1.67(4 \mathrm{H}, \mathrm{m}), 1.98(4 \mathrm{H}, \mathrm{m}), 4.26(4 \mathrm{H}, \mathrm{m})$, $5.30(1 \mathrm{H}, \mathrm{s}), 7.20(2 \mathrm{H}, \mathrm{d}(J=8.2 \mathrm{~Hz})), 7.27(4 \mathrm{H}, \mathrm{d}(J=9.7 \mathrm{~Hz})), 7.86(2 \mathrm{H}, \mathrm{d}(J=7.9 \mathrm{~Hz}))$, $8.07(2 \mathrm{H}, \mathrm{d}(J=8.2 \mathrm{~Hz})), 8.10(4 \mathrm{H}, \mathrm{d}(J=8.3 \mathrm{~Hz})), 8.16(2 \mathrm{H}, \mathrm{d}(J=7.9 \mathrm{~Hz})), 8.89(2 \mathrm{H}$, 
$\mathrm{d}(J=4.6 \mathrm{~Hz})$ ), $8.98(6 \mathrm{H}, \mathrm{m})$. MALDI TOF MS (dithranol) ; Obs. 932.2890 (Cal. for $\left.[\mathrm{M}+\mathrm{H}]^{+}=932.31\right)$. HR FABMS; found $932.3099\left(\right.$ calcd for $\left.[\mathrm{M}+\mathrm{H}]^{+}=932.3100\right)$. Anal. Calcd. For $\mathrm{C}_{57} \mathrm{H}_{52} \mathrm{~N}_{4} \mathrm{O}_{3} \mathrm{SiZn} \bullet 1.25 \mathrm{H}_{2} \mathrm{O}$ C, 71.61; H, 5.68; N, 5.78. Found: C, 71.53; H, $5.74 ; \mathrm{N}, 5.85$.

Compound 9. In a $100 \mathrm{~mL}$ of round-bottomed flask, ethanol solution (36 mL) of CsF (0.41 g, $2.7 \mathrm{mmol}, 10$ eq./8) was added to the THF $(60 \mathrm{~mL})$ and ethanol $(24 \mathrm{~mL})$ solution of $8(0.25 \mathrm{~g}, 0.27 \mathrm{mmol})$. The solution was stirred at room temperature for 21 hours. The solvent was evaporated and the residue was purified by flash chromatography (silica gel, chloroform) to produce a purple solid (200 mg, 87\%). ${ }^{1} \mathrm{H}$ NMR (600 MHz, $\mathrm{CDCl}_{3}$, TMS standard, r.t.); $\delta 1.11(6 \mathrm{H}, \mathrm{t}(J=7.4 \mathrm{~Hz})), 1.67(4 \mathrm{H}, \mathrm{m})$, $1.98(4 \mathrm{H}, \mathrm{m}), 3.31(1 \mathrm{H}, \mathrm{s}), 4.26(4 \mathrm{H}, \mathrm{t}(J=6.5 \mathrm{~Hz})), 5.30(1 \mathrm{H}, \mathrm{s}), 7.20(2 \mathrm{H}, \mathrm{d}(J=8.2 \mathrm{~Hz}))$, $7.27(4 \mathrm{H}, \mathrm{d}(J=8.4 \mathrm{~Hz})), 7.89(2 \mathrm{H}, \mathrm{d}(J=7.9 \mathrm{~Hz})), 8.07(2 \mathrm{H}, \mathrm{d}(J=8.2 \mathrm{~Hz})), 8.10(4 \mathrm{H}$, $\mathrm{d}(J=8.3 \mathrm{~Hz})), 8.18(2 \mathrm{H}, \mathrm{d}(J=8.0 \mathrm{~Hz})), 8.90(2 \mathrm{H}, \mathrm{d}(J=4.6 \mathrm{~Hz})), 8.98(6 \mathrm{H}, \mathrm{m})$. MALDI TOF MS (dithranol) ; Obs. 860.2894 (Cal. for $[\mathrm{M}+\mathrm{H}]^{+}=860.27$ ). HR FABMS; found 860.2706 (calcd for $[\mathrm{M}+\mathrm{H}]^{+}=860.2705$ ). Anal. Calcd. For $\mathrm{C}_{54} \mathrm{H}_{44} \mathrm{~N}_{4} \mathrm{O}_{3} \mathrm{Zn} \bullet 0.5 \mathrm{H}_{2} \mathrm{O} \mathrm{C}$, 74.43; H, 5.21; N, 6.43. Found: C, 74.45; H, 5.23; N, 6.40.

Compound 10. In a $25 \mathrm{~mL}$ of two neck flask, KI (16 mg, $99 \mu \mathrm{mol}, 0.5 \mathrm{eq} . / 9)$ and 6-bromo-1-hexene (32 mL, $0.24 \mathrm{mmol}, 1.2$ eq./9) was added to the DMF solution (3.5 $\mathrm{mL})$ of 9 (0.17 g, $0.20 \mathrm{mmol})$ and $\mathrm{K}_{2} \mathrm{CO}_{3}\left(0.11 \mathrm{~g}, 0.79 \mathrm{mmol}, 4\right.$ eq./9) under $\mathrm{N}_{2}$ atmosphere. The solution was stirred at $65{ }^{\circ} \mathrm{C}$ for 2 hours. The insoluble materials were filtered off and the filtrate was evaporated. Chloroform $(50 \mathrm{~mL})$ was added to the residue and the chloroform solution was washed by $\mathrm{H}_{2} \mathrm{O}(50 \mathrm{ml} \mathrm{X} \mathrm{3)}$ ) and dried over anhydrous $\mathrm{MgSO}_{4}$. The insoluble materials were filtered off, and the filtrate was purified by column chromatography (silica gel, chloroform: $n$-hexane $=3: 1$ ) to produce a purple solid (142 mg, $76 \%$ ). ${ }^{1} \mathrm{H}$ NMR (600 MHz, $\mathrm{CDCl}_{3}$, TMS standard, r.t.); $\delta 1.11$ $(6 \mathrm{H}, \mathrm{t}(\mathrm{J}=7.4 \mathrm{~Hz})), 1.68(4 \mathrm{H}, \mathrm{m}), 1.76(2 \mathrm{H}, \mathrm{m}), 1.99(6 \mathrm{H}, \mathrm{m}), 2.27(2 \mathrm{H}, \mathrm{m}), 3.31(1 \mathrm{H}, \mathrm{s})$, $4.27(6 \mathrm{H}, \mathrm{t}(J=6.0 \mathrm{~Hz})), 5.05(1 \mathrm{H}, \mathrm{d}(J=10.1 \mathrm{~Hz})), 5.13(1 \mathrm{H}, \mathrm{d}(J=17.3 \mathrm{~Hz})), 5.92(1 \mathrm{H}, \mathrm{m})$, $7.28(6 \mathrm{H}, \mathrm{d}(J=-\mathrm{Hz})), 7.89(2 \mathrm{H}, \mathrm{d}(J=7.5 \mathrm{~Hz})), 8.10(6 \mathrm{H}, \mathrm{d}(J=8.0 \mathrm{~Hz})), 8.18(2 \mathrm{H}$, $\mathrm{d}(J=7.6 \mathrm{~Hz})), 8.93(2 \mathrm{H}, \mathrm{d}(J=4.0 \mathrm{~Hz})), 8.98(6 \mathrm{H}, \mathrm{m})$. HR FABMS; found 942.3494 (calcd for $[\mathrm{M}+\mathrm{H}]^{+}=942.3487$ ). 
Compound 11. In a $25 \mathrm{~mL}$ of two neck flask, anhydrous diisopropylamine $(3.4 \mathrm{~mL}$, excess) was added to an anhydrous THF solution $(5.0 \mathrm{~mL})$ of $\mathbf{1 0}(0.13 \mathrm{~g}, 0.14 \mathrm{mmol}$, 2.2 eq./4), 4 (26 mg, $64 \mu \mathrm{mol}), \operatorname{Pd}\left(\mathrm{PPh}_{3}\right)_{4}(24 \mathrm{mg}, 21 \mu \mathrm{mol}, 0.15$ eq./4) and $\mathrm{CuI}(8.0 \mathrm{mg}$, $42 \mu \mathrm{mol}, 0.3$ eq./4). The reaction was stirred at room temperature for 4.5 hours under Ar atmosphere. The solvent was evaporated and then dichloromethane was added to the residue. The solution was washed by $5 \%$ of aqueous $\mathrm{NH}_{3}(30 \mathrm{~mL}$ X 3$)$ and $\mathrm{H}_{2} \mathrm{O}(30$ $\mathrm{mL}$ ), dried over anhydrous $\mathrm{MgSO}_{4}$. The insoluble materials were filtered off and the filtrate was evaporated. The residue was purified by column chromatography (silica gel, chloroform) and GPC (JAIGEL-2H-40 and JAIGEL-1H-40, chloroform, $10.5 \mathrm{ml} / \mathrm{min}$. $256 \mathrm{~nm})$ to produce a purple solid $(64 \mathrm{mg}, 50 \%)$. ${ }^{1} \mathrm{H}$ NMR $\left(600 \mathrm{MHz}, \mathrm{CDCl}_{3}, \mathrm{TMS}\right.$ standard, r.t.); $\delta 1.12(12 \mathrm{H}, \mathrm{t}(J=7.3 \mathrm{~Hz})), 1.69(8 \mathrm{H}, \mathrm{m}), 1.76(4 \mathrm{H}, \mathrm{m}), 1.80(6 \mathrm{H}, \mathrm{s}), 2.01$ $(12 \mathrm{H}, \mathrm{m}), 2.27(4 \mathrm{H}, \mathrm{m}), 4.28(12 \mathrm{H}, \mathrm{t}(J=6.2 \mathrm{~Hz})), 5.06(2 \mathrm{H}, \mathrm{d}(J=10.0 \mathrm{~Hz})), 5.14(2 \mathrm{H}$, $\mathrm{d}(J=17.2 \mathrm{~Hz})), 5.94(2 \mathrm{H}, \mathrm{m}), 7.28(12 \mathrm{H}, \mathrm{m}), 7.67(1 \mathrm{H}, \mathrm{d}(J=7.8 \mathrm{~Hz})), 7.74(1 \mathrm{H}, \mathrm{d}(J=7.9$ $\mathrm{Hz})), 7.87(1 \mathrm{H}, \mathrm{s}), 7.95(2 \mathrm{H}, \mathrm{d}(J=7.6 \mathrm{~Hz})), 8.00(2 \mathrm{H}, \mathrm{d}(J=7.7 \mathrm{~Hz})), 8.12(12 \mathrm{H}, \mathrm{d}(J=8.2$ $\mathrm{Hz})), 8.25(4 \mathrm{H}, \mathrm{m}), 8.96(4 \mathrm{H}, \mathrm{d}(J=4.5 \mathrm{~Hz})), 8.99(8 \mathrm{H}, \mathrm{s}), 9.02(4 \mathrm{H}, \mathrm{d}(J=4.5 \mathrm{~Hz}))$. HR FABMS; found 2040.7546 (calcd for $[\mathrm{M}+\mathrm{H}]^{+}=2040.7550$ ).

Compound 12. In a $50 \mathrm{~mL}$ of two neck flask, $\mathrm{NaOH}(0.20 \mathrm{~g}$, excess $)$ was added to an anhydrous toluene solution $(10 \mathrm{~mL})$ of $\mathbf{1 1}(60 \mathrm{mg}, 29 \mu \mathrm{mol}) .3,4,5,6$ hours after starting the reaction, $\mathrm{NaOH}(0.20 \mathrm{~g}$, excess) was added to the solution. The reaction was kept under reflux for 7 hours. The insoluble materials were filtered off. The filtrate was evaporated and the residue was purified by column chromatography (silica gel, chloroform) to produce a purple solid (41 mg ,70\%). ${ }^{1} \mathrm{H} \mathrm{NMR} \mathrm{(600} \mathrm{MHz}, \mathrm{CDCl}_{3}$, TMS standard, r.t.); $\delta 1.12(12 \mathrm{H}, \mathrm{t}(J=7.3 \mathrm{~Hz})), 1.69(8 \mathrm{H}, \mathrm{m}), 1.76(4 \mathrm{H}, \mathrm{m}), 2.01(12 \mathrm{H}$, m), $2.27(4 \mathrm{H}, \mathrm{m}), 3.58(1 \mathrm{H}, \mathrm{s}), 4.28(12 \mathrm{H}, \mathrm{t}(J=6.3 \mathrm{~Hz})), 5.06(2 \mathrm{H}, \mathrm{d}(J=11.0 \mathrm{~Hz})), 5.14$ $(2 \mathrm{H}, \mathrm{d}-\mathrm{d}(J=17.0-1.6 \mathrm{~Hz})), 5.90(2 \mathrm{H}, \mathrm{m}), 7.29(12 \mathrm{H}, \mathrm{m}), 7.72(1 \mathrm{H}, \mathrm{d}-\mathrm{d}(J=8.2-1.4 \mathrm{~Hz}))$, $7.76(1 \mathrm{H}, \mathrm{d}(J=7.7 \mathrm{~Hz})), 7.94(1 \mathrm{H}, \mathrm{d}(J=1.1 \mathrm{~Hz})), 7.96(2 \mathrm{H}, \mathrm{d}(J=7.8 \mathrm{~Hz})), 8.00(2 \mathrm{H}$, $\mathrm{d}(J=7.9 \mathrm{~Hz})), 8.12(12 \mathrm{H}, \mathrm{d}(J=8.3 \mathrm{~Hz})), 8.26(4 \mathrm{H}, \mathrm{d}(J=7.7 \mathrm{~Hz})), 8.97(4 \mathrm{H}, \mathrm{d}(J=4.5 \mathrm{~Hz}))$, $9.00(8 \mathrm{H}, \mathrm{t}(J=4.5 \mathrm{~Hz})), 9.02(4 \mathrm{H}, \mathrm{d}(J=4.6 \mathrm{~Hz}))$. HR FABMS; found 1982.7131 (calcd for $\left.[\mathrm{M}+\mathrm{H}]^{+}=1982.7131\right)$.

Compound 1o. In a $50 \mathrm{~mL}$ of two neck flask, $\mathrm{Cu}(\mathrm{I}) \mathrm{OAc}(4.7 \mathrm{mg}, 26 \mu \mathrm{mol}, 1.5$ eq./12) was added to an anhydrous pyridine solution $(8.5 \mathrm{~mL})$ of $\mathbf{1 2}(35 \mathrm{mg}, 18 \mu \mathrm{mol})$ under $\mathrm{N}_{2}$ 
atmosphere. The solution was stirred at $80{ }^{\circ} \mathrm{C}$ for 9.5 hours. After completion of the reaction, chloroform $(20 \mathrm{ml})$ was added to the reaction mixture. The solution was washed by saturated $\mathrm{NH}_{4} \mathrm{Cl}$ aqueous solution $(30 \mathrm{~mL} \mathrm{X} 2)$ and $\mathrm{H}_{2} \mathrm{O}(50 \mathrm{~mL} \quad \mathrm{X}$ 2) and dried over anhydrous $\mathrm{MgSO}_{4}$. The insoluble materials were filtered off and the filtrate was evaporated. The residue was purified by GPC (JAIGEL-2H-40 and JAIGEL-1H-40, chloroform, $10.5 \mathrm{ml} / \mathrm{min} ., 256 \mathrm{~nm})$ to produce a purple solid $(11 \mathrm{mg}, 31 \%)$. ${ }^{1} \mathrm{H} \mathrm{NMR}$ (600 MHz, $\mathrm{CDCl}_{3}$, TMS standard, r.t.); $\delta 0.98(12 \mathrm{H}, \mathrm{t}(J=7.3 \mathrm{~Hz})), 1.10(12 \mathrm{H}, \mathrm{t}(J=7.4$ $\mathrm{Hz}), 1.50(8 \mathrm{H}, \mathrm{m}), 1.66(8 \mathrm{H}, \mathrm{m}), 1.75(16 \mathrm{H}, \mathrm{m}, 16 \mathrm{H}, \mathrm{m}), 1.97(12 \mathrm{H}, \mathrm{m}), 2.02(4 \mathrm{H}, \mathrm{m})$, $2.26(8 \mathrm{H}, \mathrm{m}), 3.96(8 \mathrm{H}, \mathrm{t}(J=6.2 \mathrm{~Hz})), 4.15(4 \mathrm{H}, \mathrm{t}(J=6.2 \mathrm{~Hz})), 4.24(8 \mathrm{H}, \mathrm{t}(J=6.3 \mathrm{~Hz}))$, $4.28(4 \mathrm{H}, \mathrm{t}(J=6.3 \mathrm{~Hz})), 5.06(4 \mathrm{H}, \mathrm{d}(J=5.7 \mathrm{~Hz})), 5.13(4 \mathrm{H}, \mathrm{d}-\mathrm{d}(J=16.7-6.7 \mathrm{~Hz})), 5.94$ $(4 \mathrm{H}, \mathrm{m}), 7.04(8 \mathrm{H}, \mathrm{d}(J=8.3 \mathrm{~Hz})), 7.07(4 \mathrm{H}, \mathrm{d}(J=7.9 \mathrm{~Hz})), 7.28(4 \mathrm{H}, \mathrm{d}(J=8.5 \mathrm{~Hz})), 7.59$ $(2 \mathrm{H}, \mathrm{d}(J=7.6 \mathrm{~Hz})), 7.65(2 \mathrm{H}, \mathrm{d}(J=9.3 \mathrm{~Hz})), 7.66(4 \mathrm{H}, \mathrm{d}(J=8.0 \mathrm{~Hz})), 7.86(4 \mathrm{H}, \mathrm{d}(J=-$ $\mathrm{Hz})), 7.91(4 \mathrm{H}, \mathrm{d}(J=-\mathrm{Hz})), 7.97(2 \mathrm{H}, \mathrm{s}), 8.00(8 \mathrm{H}, \mathrm{d}(J=7.9 \mathrm{~Hz})), 8.07(8 \mathrm{H}, \mathrm{d}(J=7.9$ $\mathrm{Hz})$ ), $8.11(4 \mathrm{H}, \mathrm{d}(J=8.0 \mathrm{~Hz})), 8.14(4 \mathrm{H}, \mathrm{d}(J=7.7 \mathrm{~Hz})), 8.31(4 \mathrm{H}, \mathrm{d}(J=7.2 \mathrm{~Hz})), 8.74-8.98$ $(32 \mathrm{H}, \mathrm{m})$. MALDI TOF MS (dithranol); found 3973.42 (calcd for $\left.[\mathrm{M}+\mathrm{H}]^{+}=3973.14\right)$. Anal. Calcd for $\mathrm{C}_{256} \mathrm{H}_{218} \mathrm{~N}_{16} \mathrm{O}_{12} \mathrm{Zn}_{4} \cdot 2 \mathrm{H}_{2} \mathrm{O}$ : C, 76.71; H, 5.58; N, 5.59. Found: C, 76.40; H, $5.72 ; \mathrm{N}, 5.45$. 


\section{Synthesis of CP1 and CP2.}

CP1. CP1 was synthesized according to the synthetic procedures reported previously. ${ }^{2)}$ GPC (chloroform vs PS); $M_{n}=2765 \mathrm{~g} \mathrm{~mol}^{-1}, M_{w} / M_{n}=5.91$. UV-Vis (chloroform); $\lambda_{\max }$ $=415.0 \mathrm{~nm}$. FL (chloroform with $400 \mathrm{~nm}$ excitation); $\lambda_{\max }=459.5 \mathrm{~nm}$.

CP2. In a $25 \mathrm{~mL}$ of two neck flask, $\mathrm{PdCl}_{2}(\mathrm{dppf})_{2}(1.8 \mathrm{mg}, 0.01$ eq. $)$ was added to an anhydrous toluene $(2.5 \mathrm{~mL})$ and $\mathrm{H}_{2} \mathrm{O} \quad(0.50 \mathrm{~mL})$ solution of 2,5-bis(tert-butoxycarbonyl-methylamino)-1,4-diiodobenzene ${ }^{2)}(0.13 \mathrm{~g}, 0.22 \mathrm{mmol})$, 2,5-bis(dodecyloxy)-1,4-diiodobenzene ${ }^{2)} \quad(0.15 \quad \mathrm{~g}, \quad 0.22 \quad \mathrm{mmol}, \quad 1 \quad$ eq.), 5,5'-bis(4,4,5,5-tetramethyl-1,3,2-dioxaborolan-2-yl)-2,2'-bithiophene $\quad(0.18 \mathrm{~g}, \quad 0.43$ mmol, 2 eq.) and $\mathrm{NaHCO}_{3}(0.18 \mathrm{~g}, 2.1 \mathrm{mmol}, 10$ eq. $)$ and the solution was stirred under reflux under Ar atmosphere for 3 days. The solution was poured into ice-cold methanol $(50 \mathrm{ml})$ and stirred overnight at $0{ }^{\circ} \mathrm{C}$. The polymer was obtained as precipitate and washed with methanol, followed by being purified by GPC (JAIGEL 2.5H and JAIGEL $3 \mathrm{H}$, chloroform, $3.5 \mathrm{ml} / \mathrm{min}$., $256 \mathrm{~nm}$ ). ${ }^{1} \mathrm{H} \mathrm{NMR}$ (600 MHz, $\mathrm{CDCl}_{3}$, TMS standard, r.t.); $\delta 0.87(6 \mathrm{H}, \mathrm{m}), 1.11-1.36(32 \mathrm{H}, \mathrm{m}), 1.46(9 \mathrm{H}, \mathrm{s}), 1.51(9 \mathrm{H}, \mathrm{s}), 1.58(4 \mathrm{H}, \mathrm{m}), 1.96$ $(4 \mathrm{H}, \mathrm{m}), 2.83(6 \mathrm{H}, \mathrm{br}) 4.14(4 \mathrm{H}, \mathrm{br}), 4.64(2 \mathrm{H}, \mathrm{br}), 4.71(2 \mathrm{H}, \mathrm{br}), 6.97(2 \mathrm{H}, \mathrm{m})$, 7.21-7.36 (8H, m), $7.49(2 \mathrm{H}, \mathrm{m})$. GPC (chloroform vs PS); $M_{n}=11,500 \mathrm{~g} \mathrm{~mol}^{-1}, M_{w} / M_{n}$ $=1.35$. UV-Vis (chloroform); $\lambda_{\max }=451.5 \mathrm{~nm} \quad \mathrm{FL}$ (chloroform with $350 \mathrm{~nm}$ excitation); $\lambda_{\max }=527.0 \mathrm{~nm}$. 


\section{Measurements.}

UV-Vis and fluorescence spectral changes upon complexation between 10 and CP1.
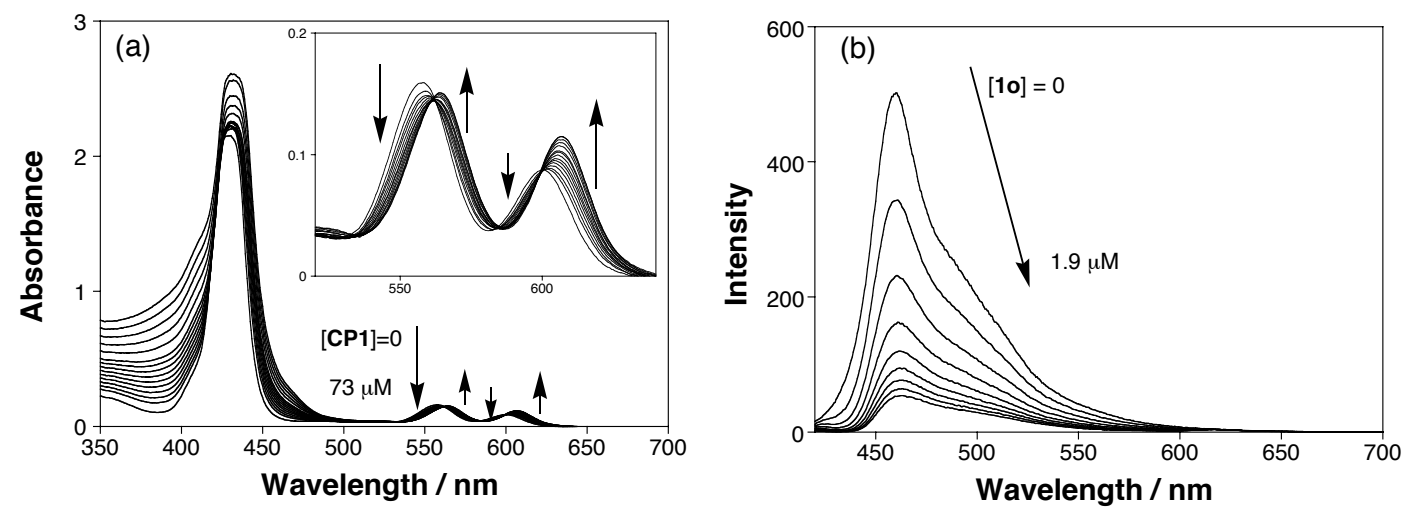

Figure S1. (a) UV-Vis spectra of $10(2.0 \mu \mathrm{M})$ upon addition of CP1 in chloroform at $25{ }^{\circ} \mathrm{C}$. Inset: magnified spectra about the $\mathrm{Q}$ bands. (B) Fluorescence spectra change of CP1 $([\mathbf{C P 1}]=27 \mu \mathrm{M})$ in the presence and absence of 10 in chloroform $\left(\lambda_{\mathrm{ex}}=400 \mathrm{~nm}\right)$.

A photograph of SEC and UV-Vis spectra of the immobilized $1 \cdot C P 1$ assemblies by the $\mathrm{RCM}$ reaction.
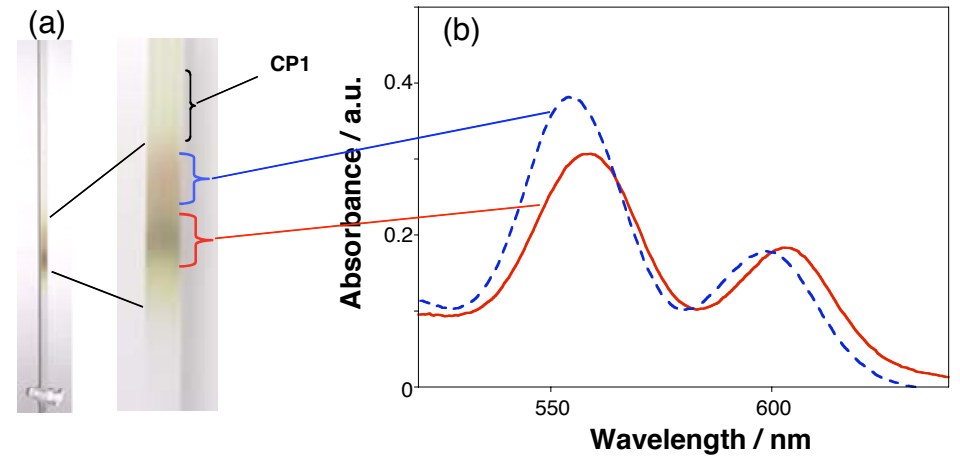

Figure S2. (a) A photograph of SEC of the immobilized assemblies. (b) UV-Vis spectra for the first and the second fraction in chloroform. The first fraction contains 1•(diamine unit in CP1) ${ }_{2}$ complex, which should be the immobilized assemblies by RCM reaction. The second fraction contains unreacted and/or uncomplexed 1 (1o and 1c). 


\section{HR TEM images of immobilized $1 \cdot \mathrm{CP1}$ assemblies.}
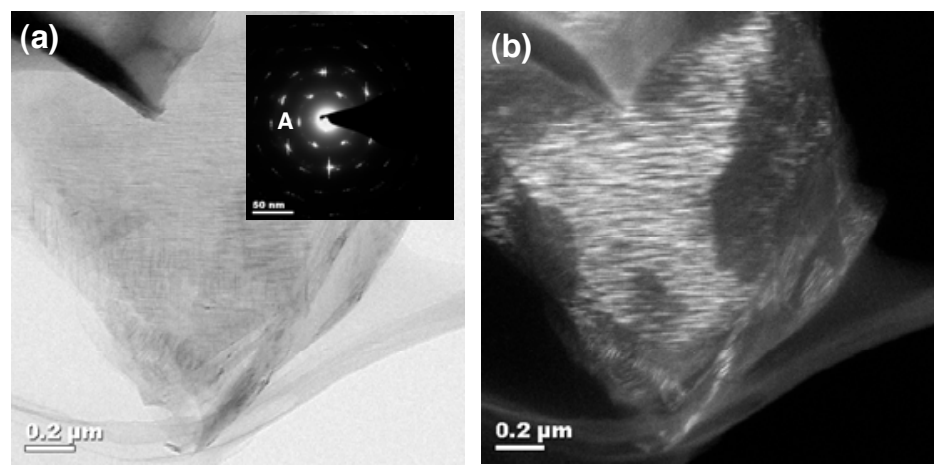

Figure S3. (a) A HRTEM image of the immobilized 1•CP1 assemblies obtained without staining. Inset: Electron diffraction pattern of (a). (b) A Dark-field diffraction contrast imaging using the reflection A.

TEM and HRTEM images of the immobilized $1 \cdot \mathrm{CP} 1$ assemblies after the acid treatment.
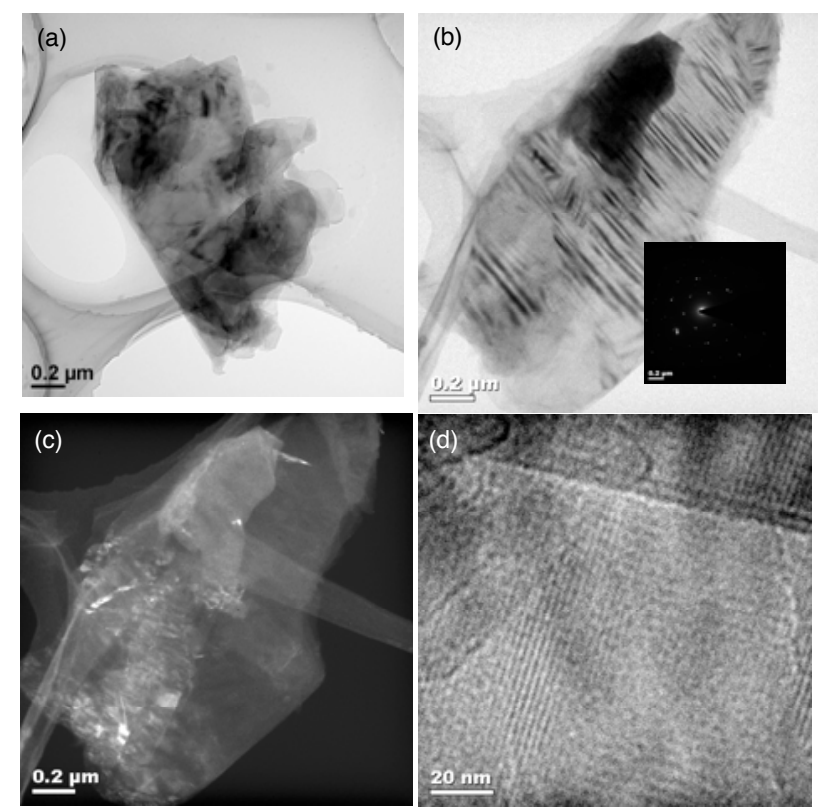

Figure S4. TEM images of (a) the immobilized 1•CP1 assemblies after TFA treatment, (b) the immobilized $\mathbf{1 \bullet C P 1}$ assemblies after mixing with $\mathrm{HCl}$ aqueous solution and then neutralized. Inset: Electron diffraction pattern of (b). (c) A dark-field diffraction contrast imaging using the reflection in inset of (b), indicating that the immobilized assemblies are crystalline even after the acid treatment. (d) A HRTEM image of (b), the periodicities of which were estimated to be $2.0 \mathrm{~nm}$, as revealed from the Fourier-filtered image. 
UV-Vis spectral changes of the immobilized $1 \cdot \mathrm{CP} 1$ assemblies after the acid/base treatment.

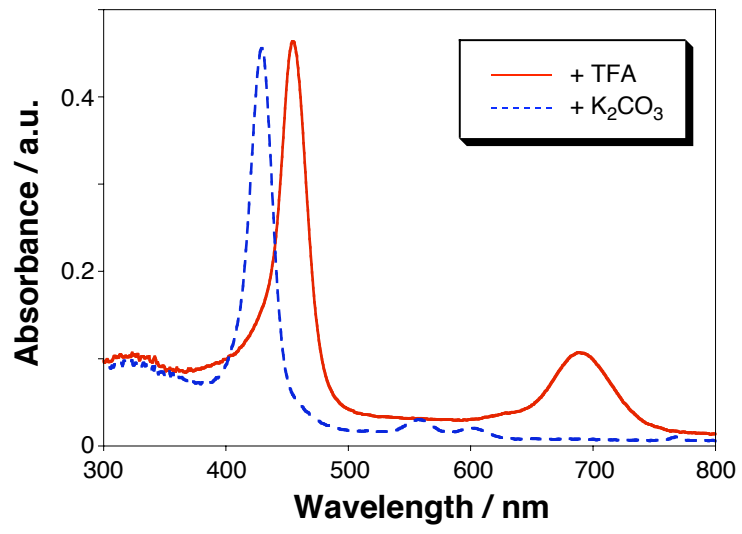

Figure S5. UV-Vis spectra of the immobilized assemblies of $\mathbf{1} \mathbf{C P 1}$ in chloroform at $25{ }^{\circ} \mathrm{C}$ upon addition of TFA (red line). Neutralization through treatment with $\mathrm{K}_{2} \mathrm{CO}_{3}$ resulted in the shift of the Soret band and Q bands (blue line). Through a process that we ascribe to re-metallation into $\mathbf{1}$ and recomplexation between $\mathbf{1}$ and $\mathbf{C P 1}$ within the immobilized assemblies.

UV-Vis spectral changes of 10 upon addition of CP2 or P4VP.
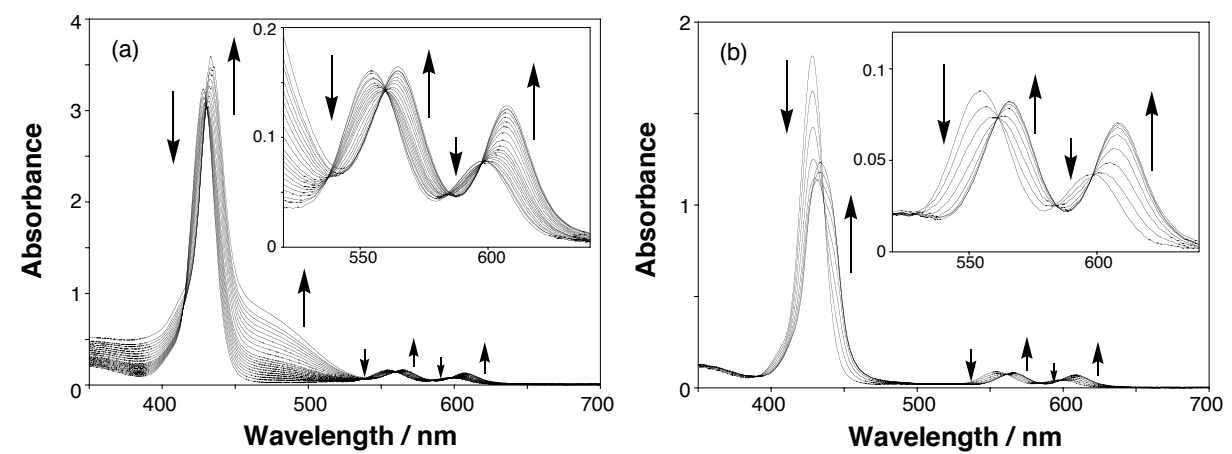

Figure S6. (a) UV-Vis spectra of $10(2.0 \mu \mathrm{M})$ upon addition of $\mathbf{C P 2}$ in chloroform at $25^{\circ} \mathrm{C}$. Optical path length is $10 \mathrm{~mm}$. Inset: magnified spectra about the Q bands. (b) UV-Vis spectra of $10(10.0 \mu \mathrm{M})$ upon addition of poly(4-vinylpyridine) in chloroform at $25^{\circ} \mathrm{C}$. Optical path length is $1 \mathrm{~mm}$. Inset: magnified spectra about the Q bands. 
TEM images of immobilized assemblies composed of 1 and CP2 or P4VP.
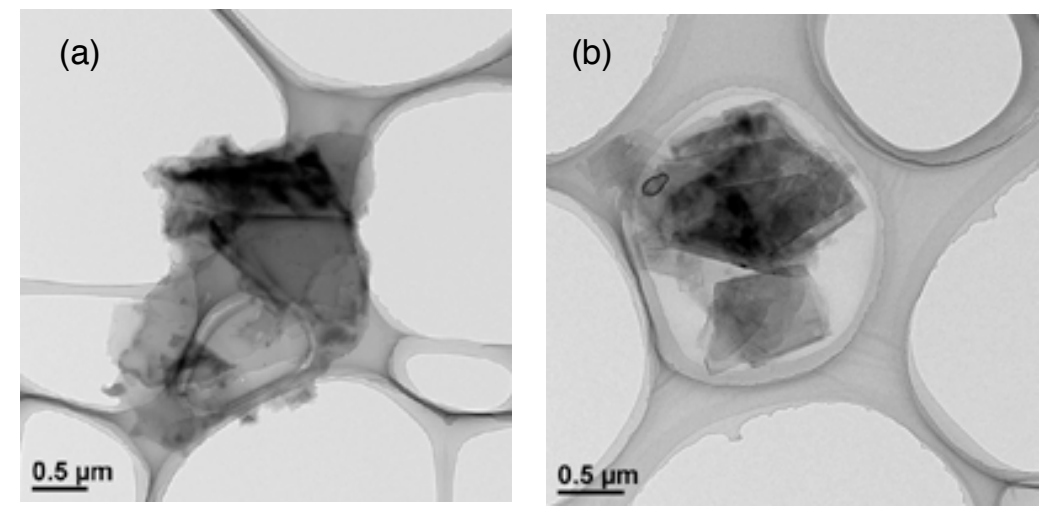

Figure 57. TEM images of (a) the immobilized 1•CP2 and (b) 1• poly(4-vinylpyridine) assemblies after the acid treatment, obtained without staining.

\section{References.}

1) Kubo, Y.; Ikeda, M.; Sugasaki, A.; Takeuchi, M.; Shinkai, S. Tetrahedron Lett. 2001, 7435-7438.

2) Kubo, Y.; Kitada, Y.; Wakabayashi, R.; Kishida, T.; Ayabe, M.; Kenji, K.; Takeuchi, M.; Shinkai, S. Angew. Chem. Int. Ed. 2005, 45, 1548-1553. 